\title{
A obra literária como fonte na pesquisa educacional: Um estudo sobre a educação brasileira na segunda metade do século XIX
}

The literary work as a source in educational research: A study on Brazilian education in the second half of the 19th century

EI trabajo literario como fuente en la investigación educativa: Un estudio sobre la educación brasileña en la segunda mitad del siglo 19

Recebido: 27/06/2021 | Revisado: 04/07/2021 | Aceito: 08/07/2021 | Publicado: 18/07/2021

\author{
Francisco Ari de Andrade \\ ORCID: https://orcid.org/0000-0002-3028-9867 \\ Universidade Federal do Ceará, Brasil \\ E-mail: andrade.ari7@gmail.com \\ Fernanda Maria Diniz da Silva \\ ORCID: https://orcid.org/0000-0002-3958-3077 \\ Secretaria da Educação Básica do Ceará, Brasil \\ E-mail: fernandamdsilva@hotmail.com
}

\begin{abstract}
Resumo
A presente pesquisa é de natureza qualitativa, de cunho bibliográfica, com enfoque na prática da pesquisa em história da educação, conforme as orientações sugeridas por Luca (2020). O presente artigo aborda as imagens das práticas pedagógicas e da relação professor-aluno no ambiente escolar brasileiro do século XIX, trazidas pela literatura de ficção, com destaque para o gênero romance. A metodologia foi desenvolvida em duas etapas, integradas entre si. $\mathrm{Na}$ primeira, foi feita a seleção de três romances publicados no século XIX: Memórias Póstumas de Brás Cubas e Conto de Escola, de Machado de Assis; O Ateneu, de Raul Pompéia; O Coruja, de Aluísio Azevedo e A Normalista, de Adolfo Caminha. Na segunda etapa, após a leitura analítica de cada uma das obras, foram apontadas passagens na narrativa que traduzem as imagens de situações do ambiente da escola brasileira, identificando-se as práticas e a relação professor-aluno. Em cada análise foi possível identificar passagens que denotam o modelo escolar existente. Os achados da pesquisa reforçam as múltiplas visões dos referidos escritores que, por meio de suas obras, apontam a configuração e a reconfiguração do sistema educacional, frente ao desenho político de um projeto republicano brasileiro.
\end{abstract}

Palavras-chave: Educação; Literatura; Fonte; Sistema escolar.

\begin{abstract}
This research is qualitative in nature, bibliographical in nature, focusing on the practice of research in the history of education, according to the guidelines suggested by Luca (2020). This article addresses the images of pedagogical practices and the teacher-student relationship in the Brazilian school environment in the nineteenth century, brought by fiction literature, with emphasis on the novel genre. The methodology was developed in two stages, integrated with each other. In the first, three novels published in the 19th century were selected: Posthumous Memoirs by Brás Cubas and Conto de Escola, by Machado de Assis; The Athenaeum, by Raul Pompéia; O Coruja, by Aluísio Azevedo and A Normalista, by Adolfo Caminha. In the second stage, after the analytical reading of each of the works, passages in the narrative that translate the images of situations in the Brazilian school environment were pointed out, identifying the practices and the teacher-student relationship. In each analysis it was possible to identify passages that denote the existing school model. The research findings reinforce the multiple views of the aforementioned writers who, through their works, point to the configuration and reconfiguration of the educational system, against the political design of a Brazilian republican project.
\end{abstract}

Keywords: Education; Literature; Source; School system.

\section{Resumen}

Se trata de una investigación de carácter cualitativo, de carácter bibliográfico, centrada en la práctica de la investigación en la historia de la educación, según los lineamientos sugeridos por Luca (2020). Este artículo aborda las imágenes de las prácticas pedagógicas y la relación maestro-alumno en el ámbito escolar brasileño en el siglo XIX, traídas por la literatura de ficción, con énfasis en el género novela. La metodología se desarrolló en dos etapas, integradas entre sí. En la primera se seleccionaron tres novelas publicadas en el siglo XIX: Memorias póstumas de Brás Cubas y Conto de Escola, de Machado de Assis; El Ateneo, de Raul Pompéia; O Coruja, de Aluísio Azevedo y A Normalista, de Adolfo Caminha. En la segunda etapa, luego de la lectura analítica de cada una de las obras, se 
señalaron pasajes de la narrativa que traducen las imágenes de situaciones en el ámbito escolar brasileño, identificando las prácticas y la relación maestro-alumno. En cada análisis fue posible identificar pasajes que denotan el modelo escolar existente. Los hallazgos de la investigación refuerzan las múltiples visiones de los escritores mencionados que, a través de sus trabajos, apuntan a la configuración y reconfiguración del sistema educativo, frente al diseño político de un proyecto republicano brasileño.

Palabras chave: Educación; Literatura; Fuente; Sistema Escolar.

\section{Introdução}

O presente artigo traz ao debate da história da educação imagens das práticas pedagógicas e da relação professoraluno, extraídas de narrativas ficcionais, nos gêneros romance e conto da literatura brasileira, do final do século XIX. Com esta pesquisa reflete-se o uso da literatura de ficção como fonte para os estudos de natureza histórica, na medida em que o fato educacional na segunda metade do século XIX é tomado para análise a partir das narrativas literárias, verificando em cada obra as imagens relacionadas às aspectos das práticas pedagógicas e relação professor-aluno, no processo ensino e aprendizagem.

Como se sabe o percurso educacional brasileiro ao longo da história tem sido marcado por um desequilíbrio entre a demanda social de educação e a qualidade do ensino oferecido. No entanto, no final do século XIX já se observa indícios da ruptura com o modelo monárquico, que modifica a concepção educacional predominante, uma vez que o Brasil passa, por exemplo, a estabelecer relações econômicas com a Inglaterra, (re)significando o binômio educação e trabalho (Ribeiro, 2000a).

É possível verificar que a literatura brasileira tem registrado a escola e suas práticas em diversas obras. As imagens literárias mostram o tipo de importância dada pela sociedade à educação elementar, na medida em que tais recortes denunciam as contradições de um projeto republicano e o alto índice da população, em idade escolar, analfabeta.

No tocante à metodologia utilizada, o trabalho é de natureza qualitativa, de cunho historiográfic, com foco na da educação brasileira, a partir do uso da literatura brasileira como fonte na pesquisa em história. A da leitura analítica dos seguintes textos, tomados como fonte, Memórias Póstumas de Brás Cubas e Conto de Escola, de Machado de Assis; O Ateneu, de Raul Pompéia; O Coruja, de Aluísio Azevedo e A Normalista, de Adolfo Caminha é possível uma reflexão crítica da forma como foi construída nossa experiência escolar

É importante ressaltar que ao estudarmos a história da educação a partir da fonte literária será considerado o tempo em que cada obra foi produzida, pois "a literatura é testemunho de si própria, portanto o que conta para o historiador não é o tempo da narrativa, mas sim o da escrita. Ela é tomada a partir do autor e sua época, o que dá pistas sobre a escolha do tema e de seu enredo, tal como o horizonte de expectativas de uma época" (Pesavento, 2008, p. 83).

Outro aspecto metodológico importante a ser destacado na elaboração desse trabalho é o seu caráter interdisciplinar aqui aventado ao aliar História, Literatura e Educação. Para Japiassu, "a interdisciplinaridade caracteriza-se pela intensidade das trocas entre os especialistas e pelo grau de interação real das disciplinas no interior de um mesmo projeto de pesquisa" (Japiassu, 1976, p.74). Logo, esse trabalho agrega contribuições de diferentes áreas em torno da compreensão da configuração da educação e de suas práticas em diferentes momentos históricos que são representados na obra literária.

\section{A Literatura como Fonte para os Estudos de Natureza Histórica}

As discussões que dizem respeito à história e à literatura inserem-se na abrangência da História Cultural, área que tem crescido e se destacado no âmbito das pesquisas acadêmicas da atualidade.

Para a História Cultural, a relação entre a história e a literatura se dá no plano epistemológico. De acordo com Pesavento:

A Literatura permite o acesso à sintonia fina ou ao clima de uma época, ao modo pelo qual as pessoas pensavam o mundo, a si próprias, quais os valores que guiavam seus passos, quais os preconceitos, medos e sonhos. Ela dá a ver sensibilidades, perfis, valores. Ela representa o real, ela é fonte privilegiada para a leitura do imaginário. Porque se 
fala disto e não daquilo em um texto? O que é recorrente em uma época, o que escandaliza, o que emociona, o que é aceito socialmente e o que é condenado ou proibido? Para além das disposições legais ou de códigos de etiquetas de uma sociedade, é a literatura que fornece os indícios para pensar como e por que as pessoas agiam desta e daquela forma. (Pesavento, 2008, pp. 82-83).

Sendo assim, a literatura, além de ser produto de seu tempo, é reflexo das condições socioculturais do meio em que os autores se inserem. Desse modo, configura-se como uma importante fonte de estudo da história e mais especificamente da história da educação brasileira. Vale ressaltar que este estudo não visa apenas analisar imagens da educação presentes na literatura, mas, sobretudo, conforme ressalta Antonio Candido: "averiguar como a realidade social se transforma em componente de uma estrutura literária, a ponto dela poder ser estudada em si mesma; e como só o conhecimento desta estrutura permite compreender a função que a obra exerce" (Candido, 2006, p. 9).

Nesse sentido, pesquisas envolvendo as contribuições da história e da literatura possibilitam não somente o estudo da história da educação, mas também a compreensão sobre o contexto histórico-social do Brasil característico dos fins do século XIX, narrado na obra literária por diferentes escritores brasileiros, tais como: Machado de Assis, Raul Pompéia, Adolfo Caminha e Aluísio Azevedo.

No que se refere à relação entre a obra literária e o campo social em que se insere, Borges explica:

No universo amplo dos bens culturais, a expressão literária pode ser tomada como uma forma de representação social e histórica, sendo testemunha excepcional de uma época, pois um produto sociocultural, um fato estético e histórico, que representa as experiências humanas, os hábitos, as atitudes, os sentimentos [...] e as questões diversas que movimentam e circulam em cada sociedade e tempo histórico. A literatura registra e expressa aspectos múltiplos do complexo, diversificado e conflituoso campo social no qual se insere e sobre o qual se refere. Ela é constituída a partir do mundo social e cultural, e, também, constituinte deste. (Borges, 2010, p. 98).

Desse modo, o uso da literatura como fonte de estudo está para além da verificação de como cada obra representa historicamente os dilemas de seu tempo. Trata-se, pois, de encarar o texto literário "na condição de entidade mediadora, isto é, valendo não por si (ou não apenas em si), mas enquanto domínio de projeção do espaço social que o engloba" (Reis, 1983, p. 290). Nessa perspectiva, aspectos como práticas pedagógicas, posturas didáticas, rotina escolar e relação professor e aluno são focalizados a partir do espaço social produzido pela obra. Afinal toda produção artística é produto de um tempo e de um lugar específicos e se relaciona à atuação do homem em interação com a sociedade.

Com efeito, ao longo do artigo, são analisadas as "imagens literárias", que se relacionam à educação. Vale ressaltar que o termo "imagens" foi utilizado por Pinto Neto (2001, p. 18), para se referir às construções mentais que contribuem com o estudo da história da educação brasileira.

Andrade também faz uso do termo "imagem literária", caracterizando-a como:

conhecimento construído sobre o objeto eleito, nas relações do indivíduo com o seu meio social, uma espécie de saber que diz alguma coisa sobre uma realidade experimentada. A manifestação de tal termo se dá por ocasião da visão de mundo do escritor, seu pertencimento a uma classe social, sua relação com os problemas de seu tempo e com os atores sociais. (Pinto Neto, 2016, p. 245).

No âmbito dos estudos literários e linguísticos, o termo imagem é bastante utilizado. Alfredo Bosi apresenta assim o conceito de imagem:

[...] a sensação visual. O ser vivo tem, a partir do olho, as formas do sol, do mar, do céu. O perfil, a dimensão, a cor. A imagem é um modo de presença que tende a suprir o contato direto e a manter, juntas, a realidade do objeto em si e a 
sua existência em nós. $O$ ato de ver apanha não só a aparência da coisa, mas alguma relação entre nós e essa aparência. (Bosi, 1977, p. 13).

À vista disso, é possível perceber que existe uma diferença entre o objeto em si e a ideia que se constrói dele. A imagem, de acordo com Bosi, situa-se no intervalo dessas duas formas, ligando-os. Tal intervalo se configura por meio do olho, ferramenta que capta a imagem e suas formas mais variantes, construindo-se a partir de sensações, imaginações, vontades. Assim sendo, "a vontade de prazer, o medo à dor, as redes de afeto que se tecem com os fios do desejo vão saturando a imaginação de um pesado lastro que garante a consistência e a persistência do seu produto, a imagem” (Bosi, 1977, p. 18).

Nesse trabalho, as imagens literárias são analisadas, principalmente em obras do gênero romance, pois esse gênero representa "um relato autêntico e completo sobre a experiência humana" (Watt, 1990, p. 27). Ademais, o realismo formal do romance permite uma "imitação mais imediata da experiência individual, situada num contexto temporal e espacial, do que outras formas literárias" (Watt, 1990, p. 32).

Ainda no que se refere à literatura como fonte histórica, Pesavento explica:

Literatura é fonte em si mesma, é testemunho de si própria, pois o que ela fornece ao historiador não é o tempo da narrativa, e sim o tempo em que a narrativa foi escrita - seu enredo contém pistas sobre o autor e também sobre a época, podendo mostrar, por exemplo, o horizonte de expectativas de um tempo, expressos em forma de literatura. (Pesavento, 2004, p. 83).

Desse modo, a partir do estudo das obras literárias são verificadas importantes aspectos da história da educação nos finais do século XIX.

Ribeiro salienta que a literatura é uma instituição social viva, que deve ser entendida como um processo "histórico, político e filosófico; semiótico e linguístico; individual e social, a um só tempo. Sua realidade transcende o texto para assumir o discurso, que conta, minimamente, com as dimensões do enunciador, do enunciado e do enunciatário" (Ribeiro, 2000b, p. 97). Nesse sentido, a obra literária fornece subsídios relevantes para a pesquisa no âmbito educacional.

No que se refere à relação entre história e literatura é importante ressaltar os estudos de Paul Ricouer. Tempo e narrativa, uma das principais fundamentações teóricas deste trabalho, é o título de uma importante obra do filósofo francês publicada pela primeira vez em 1894, mas lançada no Brasil somente dez anos depois.

A obra, que se divide em três tomos, oferece ao leitor reflexões fundamentais sobre o tempo, como, por exemplo, a proximidade entre a intenção do historiador e a do romancista ao produzir uma narrativa. Para o desenvolvimento desse trabalho, foram buscados subsídios teóricos, sobretudo no capítulo "O entrecruzamento da História e da Ficção", situado no Tomo III. Nesse capítulo, Paul Ricouer afirma que tanto a história quanto a literatura trabalham com o ato de leitura para refigurar o tempo. Assim, as duas áreas se valem das mediações imaginárias no processo de refiguração de uma experiência temporal.

Dessa maneira, o filósofo reflete que, se "a ficção é quase histórica, tanto quanto a história é quase fictícia" (Ricoeur, 1997, p.329). Para Ricoeur, a ficção se aproxima da história por trabalhar com acontecimentos irreais como se fossem fatos passados, por meio de uma voz narrativa. Já a história se assemelha à ficção, por contar acontecimentos reais, elaboradas pela presença narrativa.

Neste cruzamento que se estabelece entre a história e a literatura, o historiador se vale do texto literário não mais como uma ilustração do contexto em estudo, como um dado a mais, para compor uma paisagem dada. O texto literário lhe vale como porta de entrada às sensibilidades de um outro tempo, justo como aquela fonte privilegiada que pode acessar elementos do passado que outros documentos não proporcionam (Pesavento, 2008, p. 113). Sendo assim, a partir das contribuições de 
Ricouer e Pesavento, observa-se que o entrecruzamento entre história e literatura se dá pela refiguração do tempo durante o ato de leitura.

No âmbito da literatura, é válido ressaltar as pesquisas desenvolvidas por Antonio Candido, no livro Literatura e Sociedade, no qual explica que o aspecto externo (no caso, o social) vale, não como causa, nem como significado, mas como elemento que desempenha certo papel na formação da estrutura, tornando-se, portanto, interno. Nesse sentindo, o fator social não é tomado exteriormente, como referência temática ou enquadramento contextual, mas como elemento da própria elaboração artística. Para o estudioso, o valor de uma obra não está, pois, restrito à sua capacidade de exprimir aspectos da realidade. Por isso, é importante que as obras sejam analisadas, considerando tanto os seus aspectos sociais quanto os seus elementos literários, linguísticos e estilísticos.

\section{Breve Histórico da Educação Brasileira no Século XIX}

Os dois séculos iniciais da colonização no Brasil foram caracterizados pelo trabalho pedagógico dos jesuítas. Após a fase da catequese e das missões, a educação se voltou para a organização de uma elite que seguia os preceitos culturais presentes na Europa católica. Assim foi criado um sistema educacional elitista, que ofertava aos seus segmentos dominantes uma educação clássica e humanista, condizente com o modelo metropolitano.

Vale destacar que as atividades pedagógicas e religiosas desenvolvidas pelos missionários foram interrompidas em 1759, durante a Reforma Pombalina. A educação passou então a ser marcada pelas "Aulas Régias", que funcionaram de forma precária no Brasil.

Acerca dessa organização escolar Xavier, explica: "O país havia chegado à emancipação política destituído de qualquer forma organizada de educação escolar. Dessa maneira, o Brasil sai do Período Colonial com algumas poucas escolas e Aulas Régias insuficientes, sem um currículo regular, e com algumas escolas de nível superior, criadas na fase Joanina" (Xavier, 1994, p.60).

Em 15 de outubro de 1827, foi aprovada a primeira lei sobre o Ensino Elementar que vigorou até 1946. Essa lei abarcava os elementos que se tornaram o conteúdo curricular fundamental da escola primária: leitura, escrita, gramática da língua nacional, as quatro operações de aritmética, noções de geometria, "ainda que tenham ficado de fora as noções elementares de ciências naturais e das ciências da sociedade (história e geografia)" (Saviani, 2008, p. 126).

Em 17 de fevereiro de 1854, é baixado o Decreto n. 1.331-A que aprovou o "Regulamento para a reforma do ensino primário e secundário do Município da Corte". O principal nome desse projeto foi Luís Pedreira do Couto Ferraz, Ministro dos Negócios do Império. O documento trata sobre a organização das escolas particulares e o regime disciplinar dos professores e diretores de escolas. A lei discorre também sobre a adoção do princípio da obrigatoriedade do ensino, o que já sugere o início de um sistema nacional de ensino. Além disso, o texto apresenta pela primeira vez, de forma mais específica, a formação docente, entendendo que contexto histórico capitalista requeria a formação de um quadro docente que contribuísse com o desenvolvimento da sociedade moderna.

Em 1879, houve a reforma de Leôncio de Carvalho com o Decreto n. 7.247, de 19 de abril de 1879, que reformou o ensino primário, secundário e superior no Município da Corte. A base da Reforma é apresentada já no primeiro artigo do documento ao proclamar que "é completamente livre o ensino primário e secundário no Município da Corte e o superior em todo o Império, salva a inspeção necessária para garantir as condições de moralidade e higiene”. Assim como a Reforma Couto Ferraz, a Reforma Leôncio de Carvalho mantém a obrigatoriedade do ensino primário dos 7 aos 14 anos, a assistência do estado aos alunos menos favorecidos economicamente, a organização da escola primária em dois graus e o serviço de inspeção.

Vale ressaltar que a Reforma Leôncio de Carvalho regulamenta o funcionamento das Escolas Normais, a partir de aspectos como: currículo, nomeação de docentes, órgão dirigente e renumeração dos funcionários. Diferentemente da Reforma 
Couto Ferraz, a nova reforma prevê, por exemplo, a criação de jardins de infância para as crianças de 3 a 7 anos, biblioteca e museus escolares. Dermeval Saviani explica: "Se a Lei das Escolas de Primeiras Letras procurou equacionar a questão didático-pedagógica com o método do ensino mútuo e a Reforma Couto Ferraz o fez pela via do ensino simultâneo, a Reforma Leôncio de Carvalho sinaliza na direção do método do ensino intuitivo". (Saviani, 2008, p. 138).

No que tange ao método de ensino intuitivo, é válido salientar que, na segunda metade do século XIX, nos países da Europa e das Américas, apresenta-se como um fator relevante de renovação do ensino, juntamente com a formação de professores. A base do ensino intuitivo se relaciona ao declínio do ensino escolástico e à ascensão dos preceitos da pedagogia moderna. Diferentemente do ensino livresco, o ensino intuitivo parte do pressuposto que toda a educação deve ter início com a educação dos sentidos.

Dessa forma, a intuição é ressaltada como fator fundamental do conhecimento. O método se divide em três graus, explicados por Buisson (1897). São eles: a intuição sensível, a intuição intelectual e a intuição moral. A intuição sensível é caracterizada como a primeira etapa do método, conhecida no ensino primário e nos jardins de infância com a denominação de lições de coisas. Consiste em ensinar as crianças a ver, sentir, tocar, distinguir, medir, comparar, nomear, para depois conhecer, ou seja, educar os sentidos para depois exercê-los. A segunda forma de intuição - a intelectual - consiste no desenvolvimento da inteligência por meio do raciocínio, da abstração e da reflexão, ultrapassando a intuição sensível. A intuição moral, terceiro grau no desenvolvimento do ensino intuitivo, consiste, por sua vez, em educar a criança quanto aos aspectos morais e sociais.

No Brasil, foi somente a partir da década de 1870 que o método de ensino intuitivo se fez presente na legislação e nas discussões de natureza educacional. O método atingiu maior importância com as reformas republicanas da instrução pública, a partir de 1890, as quais consolidaram o ensino intuitivo na escola primária graduada, nos jardins de infância e na Escola Normal. Desse modo, o método representou, juntamente com a formação de professores, um dos principais elementos da difusão da escolarização das classes populares nas últimas décadas do século XIX e nas primeiras do XX, no Brasil.

É válido lembrar que o método intuitivo se constitui como referência na educação da Primeira República. Além disso, durante o século XIX cresceu o movimento pela desoficialização do ensino e as ações voltadas para a abertura de escolas a partir de entidades particulares de benemerência que se propunham a oferecer ensino gratuito.

Saviani reforça que o modelo de atividade particular no que se refere à instrução no decorrer do Segundo Império, materializou-se na figura de Abílio César Borges, o Barão de Macahubas.

Além de criar os próprios colégios, exercia um verdadeiro mecenato, distribuindo, pelos quatro cantos do país, livros por ele escritos ou traduzidos e materiais didáticos por ele inventados ou adquiridos. (Saviani, 2008, p. 141).

Em 1890 e 1891, com as reformas de Benjamin Constant, então Ministro da Instrução, Correios e Telégrafos, o Ensino Secundário era voltado para a preparação para o Ensino Superior. Sobre a reforma de Benjamin Constant, é fundamental salientar que se trata de uma reforma educacional de caráter elitista e liberal ocorrida no final do século XIX, cujas determinações legais foram relevantes para organização dos conteúdos ministrados na educação básica, assim como para a organização do método adotado no processo ensino-aprendizagem. Essa reforma almejava substituir o currículo acadêmico pelo currículo enciclopédico, ou seja, o currículo prático, característico das ideias positivistas.

De acordo com as considerações de Saviani (apud Delaneze, 2001), a reforma de Benjamin Constant traz uma escola graduada e tem por referência os grupos escolares. Essa forma de escola graduada era utilizado no final do século XIX nos países da Europa e nos Estados Unidos para viabilizar a implantação da educação popular. A ideia proposta pelos grupos escolares era permitir uma reunião de escolas agrupadas segundo as proximidades entre elas, promovendo um modelo organização escolar. 
Ainda no que se refere às ações educacionais no século XIX, é necessário mencionar a Constituição da República dos Estados Unidos do Brasil (24 de fevereiro de 1891). O texto constitucional, diferentemente da tradição do ensino religioso, determinava que "será leigo o ensino ministrado nos estabelecimentos públicos" (Art. 72, §6%).

Em 1901, vieram as reformas de Epitácio Pessoa que promoveu uma reforma do ensino que viabilizou a concretização do idealismo de Benjamin Constant, adequando a reforma deste às realidades regionais. Até então, o ensino era voltado para a frequência obrigatória, com exames preparatórios, que possibilitaram os estudantes ter acesso ao conhecimento por meio da prática seriada ou a partir de estudos individualizados acompanhados fora das escolas.

Assim, pelo que foi aqui brevemente exposto, é possível afirmar que a trajetória da histórica educacional no Brasil é fortemente caracterizada pelo desequilíbrio entre a demanda social de educação e a qualidade do ensino ofertada no âmbito escolar. Além disso, é marcada por interesses tradicionais e conservadores que resultaram em um modelo de educação elitista e visivelmente excludente.

Aliado a esse contexto verifica-se também um país assinalado pelo atraso industrial, grandes latifúndios e um contexto de maior valorização da educação superior em relação aos demais níveis de ensino. Nessa perspectiva, Azevedo explica que "a educação teria de arrastar-se através de todo o século XIX, inorganizada, anárquica e incessantemente desagregada". (Azevedo, 1976, p.76)

Destarte, ao longo do século XIX, não se observa uma articulação efetiva entre o ensino primário e o secundário. Além disso, a camada social menos favorecida se manteve à margem do processo social, educacional, cultural e econômico do país.

\section{As Imagens da Educação na Obra de Ficção}

Neste tópico são estudadas as imagens relacionadas à educação presentes nas seguintes obras: Memórias Póstumas de Brás Cubas e Conto de Escola, de Machado de Assis; O Ateneu, de Raul Pompéia, O Coruja, de Aluísio Azevedo e A Normalista, de Adolfo Caminha, levando-se em consideração tanto os aspectos históricos quanto os literários presentes nos textos selecionados. Essas obras foram publicadas na segunda metade do século XIX o que possibilita o estudo da construção da imagem da educação brasileira pós-monopólio da corrente religiosa da pedagogia de cunho tradicional, bem como do momento de transição do Brasil Monárquico para o Brasil República.

Inicialmente, destaca-se Memórias Póstumas de Brás Cubas, obra de Machado de Assis, publicada em 1881. As personagens da obra representam uma síntese não só da elite, mas também do povo daquele tempo. Machado de Assis sob o olhar do defunto retrata o caráter, a cultura, o sentimento e o modo de vida no século XIX, em interação com o mundo.

A infância do protagonista, como a de todo membro da sociedade patriarcal brasileira da época, é marcada por privilégios garantidos pelos pais. Na juventude, apaixona-se por Marcela com quem gasta muitos recursos da família. Seu pai, com o objetivo de controlar a vida desregrada do filho resolve mandá-lo para a Europa para estudar leis e alcançar o título de bacharel em Coimbra. Brás Cubas segue contrariado para a universidade. Em Portugal, a rotina sem responsabilidades não se altera muito. Com o certificado nas mãos, mas nenhuma disposição para o trabalho, o jovem retorna ao Brasil e segue sua vida desfrutando dos privilégios dos mais favorecidos do país.

Observa-se que esse tipo de atitude de estudar fora e retornar ao Brasil com seu diploma de "doutor" era uma conduta comum das classes ricas da época, o que já nos possibilita uma visão da educação do período. Brás Cubas recebeu como castigo ter que estudar Direito em Coimbra e deixa claro que, embora não tenha aprendido muito, foi diplomado:

A Universidade esperava-me com as suas matérias árduas; estudei-as muito mediocremente, e nem por isso perdi o grau de bacharel; deram-mo com a solenidade do estilo, após os anos da lei; uma bela festa que me encheu de orgulho e de saudades, - principalmente de saudades. Tinha eu conquistado em Coimbra uma grande nomeada de folião; era 
um acadêmico estroina, superficial, tumultuário e petulante, dado às aventuras, fazendo romantismo prático e liberalismo teórico, vivendo na pura fé dos olhos pretos e das constituições escritas. No dia em que a Universidade me atestou, em pergaminho, uma ciência que eu estava longe de trazer arraigada no cérebro, confesso que me achei de algum modo logrado, ainda que orgulhoso. (Assis,1997, p.56).

Segundo Teixeira (1969), até o final do século XIX, havia apenas 24 estabelecimentos de ensino superior no Brasil com cerca de 10.000 estudantes. Esse contexto histórico mostra que o diploma de um curso superior no século XIX no Brasil garantia uma posição privilegiada em um universo caracterizado por poucos letrados e um alto grau de analfabetismo. Sendo assim, para obter um diploma de curso superior naquele período era preciso ser integrante de um grupo social abastado, uma elite que ao se formar em um curso superior acabava por viver em "uma ilha de letrados num mar de analfabetos" (Carvalho, 1980, p. 51).

Ao longo da narrativa, observa-se ainda que Brás Cubas não valoriza sua vida escolar: "Unamos agora os pés e demos um salto por cima da escola, a enfadonha escola, onde aprendi a ler, escrever, contar, dar cacholetas, apanhá-las, e ir fazer diabruras, ora nos morros, ora nas praias onde quer que fosse propício a ociosos" (Assis, 1997, p.40).

Como se nota, a escola do período é caracterizada como portadora de uma metodologia cansativa e pouco atrativa de onde não raramente os alunos tentavam fugir.

A palmatória é o método educacional utilizado pelo personagem professor Barata, conforme é visto no seguinte trecho:

Ó palmatória, terror dos meus dias pueris, tu que foste o compelle intrare com que um velho mestre, ossudo e calvo, me incutiu no cérebro o alfabeto, a prosódia, a sintaxe, e o mais que ele sabia, benta palmatória, tão praguejada dos modernos, quem me dera ter ficado sob o teu jugo, com a minha alma imberbe, as minhas ignorâncias. (Assis,1997, p.40).

O uso da palmatória é proibido no Brasil. No entanto, até o século XIX, essa prática era utilizada de forma natural para educar crianças, seguindo o modelo daquelas adotadas pelas congregações Lassalistas ao longo do século XVII. Segundo Veiga:

Os lassalistas viam a correção dos atos como um meio pedagógico importante para manter a ordem em sala de aula, sendo possível punições através de palavras e de penitência e pelo uso de instrumentos como a férula, o chicote ou a disciplina (um bastão de 8 a 9 polegadas, na ponta do qual estão fixadas 4 ou 5 cordas e cada uma delas terá na ponta três nós) e finalmente a expulsão. (Veiga, 2003, p.501-502).

O professor é outra imagem destacada na obra. O profissional é menosprezado e o seu endereço é ridicularizado, conforme descrição: “... metido numa casinha da Rua do Piolho, sem enfadar o mundo com a tua mediocridade, até que um dia deste o grande mergulho nas trevas, e ninguém te chorou, salvo um preto velho, ninguém, nem eu, que te devo os rudimentos da escrita...” (Assis, 1997, p.40).

Dentre as imagens da obra, é importante destacar também a dos escravos e a dos alforriados que não recebem educação formal e limitam-se a reproduzir os ensinamentos vividos. Um exemplo disso é o alforriado Prudêncio, que comprou um escravo e praticava as mesmas barbáries que um dia sofreu e continuava se mantendo submisso ao antigo dono. Verificase, pois, que a obra apresenta o Brasil no século XIX, cuja elite era liberal influenciada pelas ideias europeias, mas ainda adepta ao escravismo.

No que se refere à educação feminina, percebe-se que na obra de Machado de Assis Eugênia é a personagem que representa a submissão relegada à figura da mulher da época. Apaixonada por Brás, a moça percebe que está sendo desprezada por ele, mas concorda com sua atitude, demonstrando uma submissão que é reflexo da educação recebida. 
Segundo John Gledson, estudioso de Machado de Assis e crítico literário: "Machado, como muitos outros romancistas do século XIX, desejava retratar a natureza e o desenvolvimento da sociedade em que vivia" (Gledson,1986. p. 16). A mulher machadiana, portanto, está relacionada ao mundo senhorial do século XIX, no qual o casamento e a família eram os poucos lugares de atuação do sexo feminino.

Brás Cubas discorre ainda sobre a formação do seu caráter que é caracterizado como produto dos ensinamentos que recebeu dos pais:

Sim, meu pai adorava-me. Minha mãe era uma senhora fraca,... temente às trovoadas e ao marido. $\mathrm{O}$ marido era na Terra o seu deus. Da colaboração dessas duas criaturas nasceu a minha educação, que, se tinha alguma cousa boa, era no geral viciosa, incompleta, e, em partes, negativa. (Assis, 1997, p.33).

Como se verifica, Brás Cubas cresceu sem limites e todas as suas vontades eram prontamente atendidas pelos pais. Segundo Zagury (2003), colocar limites é um modo de ajudar a criança a modificar o seu comportamento, sem prejudicar a sua autoestima. Além disso, segundo a professora Zagury (2003), a falta de limites ocasiona um quadro de dificuldades que vai se instalando paulatinamente, tais como: descontrole emocional; ataques de raiva; dificuldade crescente de aceitação de limites; distúrbios de conduta; desrespeito aos pais, colegas e autoridades; incapacidade de concentração e dificuldade para concluir tarefas. Todas essas características são observadas na construção da imagem do personagem Brás Cubas para quem só ele mesmo importa, assim como a sua vontade, o seu bem-estar e a sua satisfação pessoal.

Conto de escola, publicada em 1884, é outra obra de Machado de Assis, na qual as imagens literárias são significativas para o estudo da história da educação.

A obra mostra o comportamento de dois alunos diante da repressão e da violência pregadas pelas regras escolares. Raimundo, impossibilitado de realizar uma atividade escolar de gramática, resolve pedir ajuda a um colega, que em troca do favor the oferece uma moeda como pagamento. Contudo, Curvelo, um colega de sala deles, um pouco mais velho, os delata ao mestre e os dois são severamente punidos.

Ao longo da narrativa, é apresentado o primeiro contato de um garoto com situações de delação e corrupção. Além disso, mostra momentos nos quais o uso da palmatória era bastante comum. Assim, a obra nos possibilita enxergar aspectos importantes da educação do século XIX.

Nísia Floresta discorre sobre a prática da palmatória tão presente nas obras de Machado de Assis e já citada anteriormente:

O método da palmatória e da vara era geralmente adotado como o melhor incentivo para o desenvolvimento da inteligência! Não era raro ver-se nessas escolas o bárbaro uso de estender o menino, que não havia bem cumprido os seus deveres escolares, em um banco, e aplicarem-lhe o vergonhoso castigo do açoite! A palmatória era o castigo menos afrontoso reservado às meninas por mulheres, em grande parte, grosseiras, que faziam uso de palavras indecorosas, lançando-as ao rosto das discípulas, onde ousavam imprimir alguma vez a mão, sem nenhum respeito para com a decência, nem o menor acatamento ao 6 importante magistério, que sem compreender exerciam. (Floresta, 1889 , p.57-58).

O trecho acima foi retirado do livro Opúsculo Humanitário, publicado em 1853, quase 30 anos depois da promulgação da Lei Imperial que vetava o uso dos castigos físicos nas escolas, mostrando que o que reza a lei nem sempre condiz com aquilo que a sociedade experimenta em seu cotidiano.

O Ateneu, publicado em 1888, por Raul Pompéia, também é uma obra na qual as práticas educacionais são fortemente representadas. A obra narra o percurso de Sérgio pelo colégio interno Ateneu, localizado no bairro Rio Comprido, no Rio de 
Janeiro. Antes de ingressar no internato, Sérgio já tinha estudado em um externato e com um professor particular. A sua experiência no internato marca o fim da infância e o início da juventude.

O objetivo da instituição era a educação moral e disciplinada dos alunos. Vale ressaltar que no século XIX os colégios internos, frequentados pelos filhos da elite, caracterizavam-se por uma educação baseada em modelos educacionais severos e regimes autoritários.

Em O Ateneu, Raul Pompéia, de certa forma, relata autobiograficamente as suas lembranças acerca da instituição, conforme se verifica no trecho a seguir: "O internato! Destacada do conchego placentário da dieta caseira vinha próximo o momento de se definir a minha individualidade. Amarguei por antecipação o adeus às primeiras alegrias; olhei triste os meus brinquedos, antigos já!" (Pompéia,1905, p. 7).

Apartados da sociedade, quando são direcionados para essas instituições, os meninos vão pouco a pouco descobrindo a realidade do isolamento e a opressão dos colegas. A permanência no colégio, a hostilidade e as ameaças dos professores marcavam profundamente a vida dos alunos. Nos internatos, eram estabelecidas relações permeadas de controle, severa distribuição do tempo e usos diferenciados dos espaços escolares, onde todas as atividades eram executadas com total rigor.

A organização dos alunos em fila, o uso do uniforme, os horários bem definidos e pouco flexíveis para cada atividade são apenas algumas das práticas escolares voltadas para o alcance da disciplina apresentadas no texto e que ainda hoje fazem parte do contexto educacional brasileiro. Sobre tal aspecto, Foucault explica que a disciplina seria "a técnica específica de um poder que toma os indivíduos ao mesmo tempo como objetos e como instrumentos de seu exercício." (Foucault, 2008, p.143).

Desse modo, no contexto do Colégio interno, a aprendizagem é prejudicada pelo excesso de autoritarismo e pela falta de laços afetivos mais marcantes entre os internos e os dirigentes da instituição que normalmente se mantêm distantes dos alunos.

Assim, observa-se que, no decorrer da narrativa, aspectos como disciplina, medo e distanciamento afetivo são recorrentes. De acordo com Foucault:

A penalidade, a vigilância e o controle seriam então uma maneira de gerir as ilegalidades, de riscar limites de tolerância, de dar terreno a alguns, de fazer pressão sobre outros, de excluir uma parte, de tornar útil outra, de neutralizar estes, de tirar proveito daqueles. (Foucault 1987, p. 230).

A obra $O$ Coruja, de Aluísio Azevedo (1889), também é eivada de elementos voltados para a educação. O romance é ambientado na década de oitenta do século XIX e retrata questões como: casamento, herança e conflitos familiares. A trama se desenvolve em torno da amizade de dois personagens, André (Coruja) e Teobaldo.

André, garoto pouco sociável, depois de ficar órfão é acolhido por um padre que logo resolve encaminhá-lo a um colégio interno. Teobaldo, por sua vez, é rico e bonito, mas pouco querido pelos colegas do colégio. Os dois tinham em comum o sentimento de solidão. Com a chegada da vida adulta, os rapazes seguem para a corte com o objetivo de estudar. Nessa fase, as diferenças entre os dois aumentam. Enquanto Coruja dedica-se ao trabalho, Teobaldo entrega-se às festas. A partir da narração da vida dos jovens, verificam-se aspectos relevantes tanto da educação no colégio interno quanto da educação na corte.

A narrativa acaba por revelar também o ambiente de aprendizagem caracterizado por pouca afetividade e bastante autoritarismo. Sobre o processo de aprendizagem, Rodrigues explica que "a aprendizagem escolar depende, basicamente, dos motivos intrínsecos: uma criança aprende melhor e mais depressa quando se sente querida, está segura de si e é tratada como um ser singular" (Azevedo, 1976, p.174).

Sendo assim, observa-se que nas obras literárias aqui apresentadas a concretização do processo de aprendizagem é dificultada pelo distanciamento entre aluno e professor e pela falta de entendimento acerca do significado do que está sendo ensinado. 
Outro aspecto relevante a ser observado, na obra citada de Aluísio Azevedo, é que Teobaldo vê um mundo de possibilidades por ser rico e por poder arcar com suas despesas financeiras. Já André, o Coruja, assim como Maria do Carmo, personagem de Adolfo Caminha, não encontra outra escolha a não ser exercício do magistério como forma de alcançar uma melhor posição na sociedade.

A Normalista, de Adolfo Caminha (1893), é outra obra da literatura brasileira na qual as imagens no âmbito educacional são importantes não só para a construção da narrativa, mas também para a compreensão do contexto histórico na qual está inserida.

A obra descreve traços da região de Fortaleza, Ceará, e sua sociedade no final do século XIX. A cidade é representada como um lugar simples, sem luxo e repleto de preconceitos. O livro conta a história de Maria do Carmo, que é entregue por seu pai ao padrinho para que fosse criada longe da pobreza da seca do sertão. Inicialmente, Maria do Carmo estuda em um colégio religioso e depois passa a estudar na Escola Normal.

A obra de Caminha nos apresenta características da educação na Escola Normal, tais como: o comportamento das normalistas e as leituras realizadas pelas jovens. Em A Normalista as personagens masculinas, inclusive, discorrem sobre a educação feminina:

A educação feminina [...] é um mito ainda não compreendido pelos corifeus da moderna pedagogia. Queríamos introduzir no Ceará os dissolventes costumes parisienses a fortiori, mas não eram essas as tendências do nosso povo essencialmente católico e essencialmente crédulo. [...] O que é a Escola Normal, não me dirão? Uma escola sem mestres, um estabelecimento anacrônico, onde as moças vão tagarelar, vão passar o tempo a ler romances e maldizer o próximo, como vocês sabem melhor que eu... (Caminha, 1973, pp.203-04).

Nesse contexto, a mulher é pouco valorizada e a sua educação é sempre voltada ao bom desempenho da condição de mãe e esposa. Assim, a capacidade intelectual e profissional da mulher era esquecida

Sendo assim, ao analisar Memórias Póstumas de Brás Cubas e Conto de Escola, de Machado de Assis; O Ateneu, de Raul Pompéia; O Coruja, de Aluísio Azevedo e A Normalista, de Adolfo Caminha, é possível perceber que a escola, suas práticas e seus atores são representados, em geral, como modelos de autoritarismo que distanciam professor e aluno e que tornam o processo ensino-aprendizagem difícil tanto para quem ensina como para quem busca aprender.

Além disso, embora sejam obras situadas no período de transição da Monarquia para a República, a escola é apresentada como uma instituição que ainda precisa se desenvolver muito, uma vez que é vista como um lugar de opressão onde o educando não percebe o significado do que é ensinado e o professor mantém estratégias conservadoras e repressivas de ensino.

\section{Considerações Finais}

Ao longo do trabalho, foi demonstrada a importância da literatura como fonte de estudo e de reflexão para a história da educação, a partir da análise de obras de ficção. Assim a realidade social brasileira é focalizada a partir da análise de romances brasileiros, publicados no período de transição da Monarquia para a República.

A partir do foi que focalizado, é possível observar que, em geral, a escola apresenta ao longo do século XIX práticas opressoras que não preparam o educando para superar os desafios da vida fora do espaço escolar. Além disso, a prática pedagógica representada nas obras se volta para uma sociedade na qual as amarras da repressão e da exploração estão vigentes. Afinal:

A prática escolar consiste na concretização das condições que asseguram a realização do trabalho docente. Tais condições não se reduzem ao estritamente "pedagógico", já que a escola cumpre funções que lhe são dadas pela 
sociedade concreta que, por sua vez, apresenta-se como constituída por classes sociais com interesses sociais antagônicos. A prática escolar, assim, tem atrás de si condicionantes sociopolíticos que configuram diferentes concepções de homem e de sociedade e, consequentemente, diferentes pressupostos sobre o papel da escola, aprendizagem, relações professor-aluno, técnicas pedagógicas etc. (Libâneo, 2006, p. 19).

Ademais, a educação brasileira até o século XIX é caraterizada pela marca religiosa oriunda ainda das práticas Jesuítas. A educação era privilégio das elites e o povo pouco tinha acesso ao conhecimento formal.

É importante ressaltar que muitas imagens relacionadas à área educacional que foram retratadas na ficção da segunda metade do século XIX ainda permanecem fortalecidas em pleno século XXI, por meio da desvalorização da atividade do magistério, de práticas pedagógicas desvinculadas da realidade e de instituições escolares que não atendem às necessidades dos seus estudantes. Diante disso, é inegável que, embora a educação brasileira tenha se desenvolvido ao longo da história, ainda há muitos desafios a serem superados, sobretudo no que se relaciona ao currículo, à formação de professores e à valorização da escola enquanto instituição fundamental para o desenvolvimento integral do ser humano.

Trazer ao debate acadêmico uma reflexão sobre experiências educacionais retratada pela literatura clássica nacional é sempre uma oportunidade para se ampliar o leque de investivação social, principalmente por se tratar de uma tentativa de aproximação das novas gerações às questões de um tempo que, de alguma maneira, interferiram no andamento da escola pública brasileira. Nesse sentido, tal estudo instiga futuras pesquisas que possam esclarecer os percursos e nos itinerários das da construção do nosso sistema escolar, na medida em que cria a oportunidade pra auma reflexão das prática pedagógicas.

Assim, a relevância de um estudo dessa natureza está, sobretudo, em demonstrar, no campo histórico, o lugar reservado à escola, nas narrativas, conforme o projeto de sociedade brasileira que vislumbrava alcançar um ideal republicano que somente será concretizado quando a educação de qualidade for de fato um direito de todos.

\section{Referências}

Andrade. F. A. (2021). O sertão de costas para a Reforma Educacional do Ceará: Juazeiro do Norte não responde ao Cadastro Escolar. Research, Society and Development,10, 1-11

Assis, M. (2001) Memórias Póstumas de Brás Cubas. Martin Claret.

Assis, M. (2008) Conto de escola. Escala Educacional, 2008.

Azevedo, A. (2008). O Coruja. Global.

Borges, V. R.(2010) História e Literatura: Algumas Considerações. Goiás: Revista de Teoria da História. 3, pp.94-109, https://www.revistas.ufg.br/.

Bosi, A.(1977) O ser e o tempo da poesia. Cultrix.

Buisson, F. (1897) Conférence sur l'enseignement intuitif. In: Conférences pédagogiques faites aux instituteurs delegues à l'Exposition Universelle de 1878. Librairie Ch. Delagrave.

Caminha, A. (1936) A Normalista. J. Fagundes, 1936.

Candido, A.(2006) Literatura e sociedade. Ouro sobre azul.

Floresta, N. (1987). Opúsculo humanitário. Cortez, INEP.

Foucault, M. (2008). Microfísica do Poder. Edições Graal.

Gledson, J. (1986). Machado de Assis: ficção e história. Paz e Terra.

Japiassu, H.(1976). Interdisciplinaridade e Patologia do saber. Imago.

Libâneo, J. C. (2006). Democratização da escola pública: a pedagogia crítico-social dos conteúdos. Edições Loyola.

Luca, T. R. (2020). Práticas de pesquisa em História. Contexto.

Luchese, T. A. Fernandes, C.C \& Belusso, G. Instituições, histórias e culturas escolares. Educs, 2018.

Meyhi, J. C. S. \& Seawright, L.(2020). Memórias e narrativas. História oral aplicada. Coxtexto 
Research, Society and Development, v. 10, n. 8, e57810817613, 2021

(CC BY 4.0) | ISSN 2525-3409 | DOI: http://dx.doi.org/10.33448/rsd-v10i8.17613

Pesavento, S. J.(2004). História \& História Cultural. Autêntica.

Pesavento, S. J. (2008). História \& História Cultural. Autêntica,.

Pinto Neto, P. C. (2001). Ciência, literatura e civilidade. Tese (Doutorado em Educação) - Universidade Estadual de Campinas, Programa de Pós-Graduação em Educação. Campinas. <http://www.bibliotecadigital.unicamp.br/document/.

Pompéia, R. (1995). O Ateneu. Scipione.

Ribeiro, M. L. S. (2000a). História da educação brasileira: a organização escolar. Campinas: Autores Associados.

Ribeiro, L. F. (2000b). Geometrias do Imaginário. Edicións Laiovento.

Saviani, Demerval. (2008). História das ideias pedagógicas no Brasil. Autores Associados.

Teixeira A. O ensino superior no Brasil - análise e interpretação de sua evolução até 1969. Fundação Getúlio Vargas, 1969.

Watt, Ian. A ascensão do romance. Companhia das Letras, 1990.

Xavier, M. E. S. P. et al. História da Educação: a escola no Brasil. FTD,1994.

Zagury, T.(2203) Limites sem trauma. Record. 